РОЛЬ І МІСЦЕ ҐЕНДЕРНОГО РЕСУРСУ
В СИСТЕМІ ДЕРЖАВНОЇ ПОЛІТИКИ

\title{
THE ROLE AND PLACE OF GENDER RESOURCES IN THE PUBLIC POLICY SYSTEM
}

У статті розглядається основне поняття ґендерного ресурсу в системі державної політики, визначається ії роль та місце в державній політиці. Розглядаються кадровий та інтелектуальний потенціал ґендерного ресурсу з погляду державного управління, економічні та галузеві аспекти, на які впливає ґендерна політика. Даються рекомендації з основних напрямів ґендерної політики в умовах, які склалися в даний проміжок часу в Україні.

Есективному використанню в державній політиці й управлінні потенціалу громадян України - чоловіків і жінок - перешкоджають подвійні стандарти, які існують в нашому суспільстві, коли рівність прав і можливостей людей обох статей офріційно визнається, але відкидається в повсякденних практиках, заснованих на традичійних уявленнях про ролі чоловіків і жінок в сім'ї та суспільстві. Це особливо яскраво проявляється у проведенні кадрової політики в організаціях усіх типів і форм власності, зокрема і в державних органах, коли за інших рівних умов перевага в посадовому просуванні віддається чоловікам.

Визначено суперечність між наявністю об'єктивного запиту соціуму на більш широке використання в державному управлінн сочіальних ресурсів, зокрема й ґендерного, недостатньою розробленістю цієї тематики у вітчизняних наукових дослідженнях політики та державного управління. Також досліджувана проблематика зачіпає так значущі фоеномени, що мають ґендерний вимір, як соціальні підстави і ресурси політичної влади й управління, моделі організації політичної влади і владних відносин, види державної політики, взаємодія держави і громадянського суспільства у процесах модернізації. Однак усі ці феномени виявляються маловивченими з позиції знання в контекст змінення української реальності.

Отже, розроблення теоретичної концепціі одного з нетрадиційних (нематеріальних) ресурсів державної влади й управління ґендерного ресурсу, як можливості викори стання для вирішення завдань суспільного розвитку, здатності і можливості людей до біологічного й соціального відтворення, що визначаються ґендерною системою суспільства, стає актуальним науковим завданням. Його практичним застосуванням виступає обгрунтування механізмів інтенсисрікації державної політики у сфері ґендерних відносин, підвищення ефрективності застосування ґендерного ресурсу державної політики й управління на соціальному й інститучійному рівнях.
Ключові слова: ґендерний ресурс, державна політика, ґендерна політика, ресурси державної влади, соціально-політичний інстиmym

The article considers the basic concept of gender resources in the system of public policy, and defines its role and place in public policy. The human and intellectual potential of the gender resource, from the point of view of public administration, economic and sectoral aspects influenced by gender policy are considered. Recommendations are given on the main directions of gender policy in the current conditions in Ukraine. The effective use of the potential of Ukrainian citizens - men and women - in public policy and management is hampered by double standards that exist in our society, when equal rights and opportunities for people of both sexes are officially recognized but rejected in everyday practices based on traditional notions of male and female roles. women in the family and society. This is especially evident in the conduct of personnel policy in organizations of all types and forms of ownership, including government agencies, when, other things being equal, preference in promotion is given to men.

The contradiction between the existence of an objective demand of society for wider use of social resources, including gender, in public administration and the insufficient development of this topic in domestic research in politics and public administration has been identified. Also, the researched issues affect such significant phenomena that have a gender dimension as social bases and resources of political power and management, models of organization of political power and power relations, types of state policy, interaction of state and civil society in modernization processes. However, all these phenomena are insufficiently studied from the standpoint of knowledge in the context of changing Ukrainian reality.

Thus, the development of a theoretical concept of one of the non-traditional (intangible) resources of state power and management - gender resource, as an opportunity to use to solve problems of social development, ability and ability of people to biological and social reproduction, determined by gender system of society, becomes an urgent scientific task. Its practical application is the substantiation of mechanisms for intensification of state policy in the field of gender relations, increasing the effectiveness of the use of gender resources of public policy and governance at the social and institutional levels. Key words: gender resource, state policy, gender policy, resources of state power, socio-political institution.
Постановка проблеми в загальному вигляді. Держава, коли виконує свої функції як соціально-політичний інститут, має реалізовувати спільний інтерес і підтримувати рівновагу в суспільній системі, не допускати деструк- тивних конфліктних взаємодій окремих соціальних груп. Варто детально розглянути суперечності інтересів ґендерних груп, з'ясувати наслідки, що ведуть до появи нових сучасних форм ґендерних відносин. Усе це дозволяє 
порушити питання про ґендерні ресурси державної політики й управління, з'ясувати походження та потенціал, пов'язаний із необхідністю забезпечення біологічного й соціального відтворення населення.

Аналіз останніх досліджень і публікацій. Проблема ролі ґендерного ресурсу в державній політиці, їі впливу на сучасне суспільство країни та державну політику безпосередньо пов'язана із проблемою доцільності та ступенем впливу втручання держави в ґендерні питання. Більшість досліджень у цій галузі базуються на відомих роботах [3; 4; 5].

Виділення не вирішених раніше частин загальної проблеми. Незважаючи на те, що ґендерне питання та зростання його актуальності $€$ досить популярним напрямом для аналізу і наукових диспутів, вплив державного управління на ґендерну політику в державі вивчається недостатньо. Стало зрозумілим, що такий вплив має обмеження, тому виявлення нових суперечностей потребує подальшого дослідження в руслі сучасних теорій.

Мета статті - визначення ролі та місця ґендерного ресурсу державної політики, вивчення сучасних механізмів формування державної політики управління ґендерними ресурсами в державі.

Виклад основного матеріалу. Почнемо з визначення основних понять. У «Тлумачному словнику сучасної української мови» ресурс визначається як:

- запас, джерело чого-небудь;

- грошові цінності, джерело фінансових доходів.

У політиці під ресурсами розуміється сукупність засобів, застосування яких забезпечує можливість суб'єкту влади здійснювати визначальний вплив на діяльність і поведінку об'єкта.

Якщо визнати підстави влади як «відносини панування людей над людьми», можна назвати це ресурсами влади, виділяють дві такі підстави - силу й авторитет. На практиці обидва вони можуть існувати поза та відокремлено від політичних інститутів, тому що породжуються більш загальними причинами, ніж державна організація суспільства. Сила бере початок із біолого-генетичної стратифікації, коли паном $€$ той, хто сильніший фізично. Особливість силових ресурсів держави - легальність застосування сили та наявність спеціально створених збройних силових структур. Тільки держава має «монополію легітимного фізичного насильства» і виступає «єдиним джерелом «права» на насильство» [5].

Авторитет визначається довірою до джерела влади, який з'являється завдяки пози- тивній реакції на особисті якості суб'єкта влади (повага); на його компетентність і відповідальність (довіра), на стиль здійснення владних впливів (прийнятність). Ефективною вважається влада, яка може досягати необхідних дій від об'єкта владного впливу без прямого застосування сили, тобто вона заснована насамперед на авторитеті.

Ресурси державної влади - це потенційні можливості, кошти, які вона може використовувати для здійснення своїх повноважень, функцій. Залежно від етапу суспільно-політичного розвитку конкретної країни і політичного режиму ресурси влади істотно різняться. Вони мінливі, рухливі, водночас традиційні. На ранніх етапах суспільного розвитку ресурсом влади виступала сила. На стадії капіталістичного розвитку превалювало багатство, гроші. У постіндустріальних країнах знання й інформація стають основним ресурсом розвитку виробництва, влади і суспільства загалом [3, с. 187].

Динаміка зміни виду головних ресурсів влади з якістю управління. У примітивних суспільствах влада спиралася на загрозу фізичної розправи, її якість була низькою. В індустріальних суспільствах, коли на перший план виходять економічні ресурси, якість влади підвищується до середнього рівня. У постіндустріальних суспільствах більш значущим стає інформаційний ресурс, з'являється економіка знань. У суспільствах такого типу влада набуває вищої якості, тому що заснована на невичерпних, загальнодоступних і демократичних ресурсах, якими виступають знання [1].

Підкреслимо, що ресурси влади будуть використовуватися найбільш ефективно, коли «нарощування потенціалу легітимності та внутрішньої стійкості політичної сфери максимально відповідає потребам соціального розвитку», тобто інтереси влади і суспільства збігаються.

Отже, ресурси державної влади й управління - це ті потенційні можливості, які держава може використовувати для виконання своїх функцій, з метою здійснення повноважень державних органів. Вони можуть бути як силовими, так і заснованими на авторитеті, економічних і / або інформаційних можливостей.

Для реалізації своїх функцій, пов'язаних із досягненням загальних цілей процвітання та благополуччя населення, держава може задіяти ресурси громадянського суспільства. У такому разі до владних ресурсів «підпорядкування» і легітимного насильства додаються ресурси, що формуються відносинами партнерства, співпраці, кооперації, 
виникає синергетичний ефект від взаємодії держави та громадян, державних органів і громадських, комерційних організацій. У такій ситуації співробітництва вертикальні зв'язки між державою і громадянами та громадянським суспільством часів традиційного суспільства переростають у горизонтальні неієрархічні зв'язки суспільства постіндустріального, мережевого. Держава водночас не втрачає своєї функції визначення мети, але змінюється її характер, держава припиняє бути єдиним суб'єктом у суспільстві, у якому розвиваються процеси самоврядування й самоорганізації. У цьому і полягає процес демократизації політичної системи постіндустріального суспільства [6].

Ключовим моментом для державного управління виступає легальність володіння ресурсами. Зазначимо, що в деяких ситуаціях люди, які виконують державні функції, можуть вдаватися до реалізації своїх політичних цілей за допомогою ресурсів влади, якими вони не були наділені (наприклад, хабар, незаконне використання державних коштів або перевищення службових повноважень). У такому разі влада не є державною за свого джерела; вона може вважатися державною тільки за суб'єктами. Додамо, що зазвичай такі дії офіційних осіб кваліфікуються як посадові (кримінальні) злочини, тому що чиновник (політик) є володарем цих ресурсів через свої посадове становище, але використовує їх не у громадських, а в особистих цілях. Ресурси влади - це реальні та потенційні кошти, які можуть бути використані для її зміцнення.

Під час детального вивчення можемо зробити висновок про подвійність держави як соціально-політичного інституту, якщо обговорювати політизацію ґендерних відносин. Як знаряддя соціальних сил, що прийшли до влади, держава повинна реалізовувати їхні класові інтереси, як гарант суспільної злагоди - проводити війну всіх проти всіх, вона повинна працювати на загальне благо [2].

Очевидно, що універсальним ресурсом влади й управління виступає людина, оскільки саме вона своєю діяльністю створює всі інші ресурси. Як носій здатності до праці й доцільної діяльності людина формує економічні ресурси.

Тепер варто визначити місце ґендерного ресурсу в загальній системі ресурсів державної політики й управління. Розмаїття цих ресурсів із необхідністю ставить завдання їх класифікації. Поки не склалося єдиного підходу в цьому питанні, існує безліч класифікацій, побудованих за різними критеріями. Отже, ґендерний ресурс може бути класифікований так:
- з погляду сфер суспільного життя він належить водночас до соціальних (соціальний статус ґендерних груп), інформаційно-культурних (ґендерні норми і цінності), а також демографічних (ролі людей у біологічному відтворенні населення);

- у класифікації А. Етционі він може бути віднесений до ресурсів нормативного типу, тому що ґендерні ролі, норми та цінності, засвоєні у процесі ґендерної соціалізації, багато в чому визначають сприйняття жінками факту чоловічого панування в суспільстві;

- у комунікаційній теорії ґендерний ресурс може бути віднесений до ресурсів впливу та доступу до ухвалення рішень. Саме в цій сфері найяскравіше проявляється ґендерна нерівність, група жінок має значно менші можливості впливу й ухвалення рішень, ніж група чоловіків. Водночас жінки, через особливості ґендерних ролей, частіше використовують маніпулятивні технології впливу на рівні міжособистісної взаємодії;

- $з$ погляду типу ресурсу ґендерний ресурс можна віднести до нетрадиційних, тому що його ефективне використання буде прямо пов'язане з розвитком цивільної політичної культури. Якщо в суспільстві домінує підданська політична культура або патріархальна (традиційна), то ґендерний ресурс буде розтрачуватися, використовуватися екстенсивно. Отже, ґендерний ресурс більшою мірою належить до соціокультурних та ідеологічних ресурсів, ніж до економічних або утилітарних. Водночас його використання має для суспільства яскраво виражені економічні та демографічні наслідки [3].

Зазначимо, що ґендерні відносини в сучасному суспільстві мають політичний характер через об'єктивне існування й обговорення в публічному дискурсі ситуацій ґендерної нерівності. Однак використання державою ґендерного ресурсу передбачає не загострення конфлікту ґендерних груп, а пошук зон їхніх спільних інтересів. Важливо розуміти, що ці зони задані об'єктивно й пов'язані з необхідністю не тільки біологічного відтворення населення, але виконанням одного з функціональних імперативів стабільності соціальної системи, який можна назвати збереженням і відтворенням зразка, або реалізацією функції соціального відтворення, у якому існують не матеріальні блага, товари чи послуги, а соціальні норми, зразки рольової поведінки, культура в широкому розумінні цього слова.

Особливість ґендерного ресурсу, як і ґендерних відносин загалом, полягає в його об'єктивності й самовідтворюваності. Він існує незалежно від того, рефлексують полі- 
тики та державні діячі щодо цього чи ні. Люди завжди і всюди вступають в соціальній взаємодії як чоловіки і жінки, навіть тоді, коли їхній ґендер не має для них жодного значення. Можемо назвати це явище «окулярами ґендеру», які автоматично поміщають жінок і чоловіків у різні й нерівні життєві ситуації. у процесі залучення до культури індивідуум поступово засвоює окуляри культури, тим самим прагне сформувати свою особистість відповідно до них [1].

Державні цивільні службовці, будучи соціальним субстратом державного управління, об'єктивно є водночас чоловіками і жінками. Це означає, що вони привносять власні ґендерні норми, цінності та стереотипи в свою професійну діяльність, у виконання своїх посадових обов'язків, хоча найчастіше роблять це абсолютно несвідомо.

Висновки. Ґендерні відносини є потенційно політичними (конфліктні), тому що для набуття ними політичного характеру в повному розумінні слова необхідна рефлексія протилежності інтересів жінок і чоловіків, обговорення проблем їхньої нерівності в публічному дискурсі. Це завдання виконали фемінізм і жіночі дослідження як теоретична рефлексія жіночого руху. Онтологічні підстави для застосування ґендерного ресурсу державної політики й управління на інституційному рівні створюють ґендерні проблеми, які існують у всіх підсистемах державного управління: інституційній, нормативно-правовій, функціонально-структурній, комунікативній, професійно-кадровій, професійно-культурній.

\section{ЛІТЕРАТУРА:}

1. Оксамитна С. Ґендерні аспекти праці та політики у дзеркалі громадської думки. Жінки в політиці: міжнародний досвід для України : матеріали Міжнародного наукового семінару, м. Київ, НаУКМА, 7 жовтня 2005 р. : збірник наукових статей. Women and politics in Ukraine: Benefiting from International Experience. Київ : Атіка, 2006. С. 156-174.

2. Організаційні та правові елементи інституційного механізму забезпечення гендерної рівності в Україні / О. Пищуліна та ін. Видання в межах «Програми рівних можливостей та прав жінок в Україні». Запоріжжя : Друкарський світ, 2011. 140 с.

3. Грицяк Н. Формування ґендерної політики в Україні: проблеми теорії, методології, практики : монографрія. Київ : Вид-во НАДУ, 2004. 384 с.

4. Карпачова Н. Принцип рівноправності: політичні права жінок у контексті ґендерної перспективи : монограсрія. Київ : Юридична думка, 2007. C. 219-243.

5. Кресіна І. Ґендерний аналіз політичного процесу в Україні : монограсрія. Київ : Юридична думка, 2007. С. $178-218$.

6. Пашко Л. Принципи управління людськими ресурсами як основа дієвості суб'єкт-об'єктной взаємодії. Державне управління: теорія та практика. 2010. № 2. URL: http://www.academy.gov.ua/ej/ej12/ txts/10plasov.pdf (дата звернення 15.01.2021). 